\title{
FACTORS THAT AFFECT TURNOVER INTENTION IN MILLENNIAL EMPLOYEES
}

\author{
Andyani Sukmasari ${ }^{1}$ \\ ${ }^{1}$ Sekolah Tingggi Ilmu Ekonomi Media Nusantara Citra, Jl. Arteri Kedoya, Jakarta, Indonesia \\ Email: andyanisukmasari@gmail.com
}

\author{
Article History \\ Received: 7 February 2020 \\ Revision: 12 February 2020 \\ Accepted: 12 February 2020 \\ Published: 18 May 2020
}

\begin{abstract}
The biggest challenge for companies today is thinking about various strategies in retaining millennial generation employees in order to reduce turnover intention, in which turnover intention is the reaction of employees to what is felt in the company. Factors such as strong organizational culture and employee motivation are expected to retain employees to reduce turnover intention. Therefore, the purpose of this study is to see whether organizational culture and motivation are factors that can affect turnover intention of millennial employees who are in Jabodetabek. This research is quantitative in nature, conducted by survey using a questionnaire. Data were analyzed using Structural Equation Model (SEM). The results of the first study indicate that there is an influence between organizational culture on employee motivation. Second, there is an influence between organizational culture on employee turnover intention. Third, there is an influence between motivation on employee turnover intention. Furthermore, the four motivations mediate between organizational culture and employee turnover intention in Jabodetabek.
\end{abstract}

Keywords: Organizational Culture, Motivation, Turnover Intention, Millennial Generation

Abstrak. Tantangan terbesar bagi perusahaan saat ini yaitu memikirkan berbagai macam strategi dalam mempertahankan karyawan generasi milenial guna menekan angka turnover intention, yang mana turnover intention reaksi dari karyawan terhadap apa yang dirasakan di dalam perusahaan. Faktor seperti budaya organisasi yang kuat dan motivasi karyawan diharapkan dapat mempertahankan karyawan untuk menekan terjadinya turnover intention. Oleh karena itu tujuan dari penelitian ini melihat apakah budaya organisasi dan motivasi merupakan faktor yang dapat mempengaruhi turnover intention pada karyawan milenial yang berada Jabodetabek. Penelitian ini bersifat kuantitatif, dilakukan dengan survei menggunakan kuesioner. Data dianalisis dengan menggunakan Structural Equation Model (SEM). Hasil penelitian pertama menunjukkan terdapat pengaruh antara budaya organisasi terhadap motivasi karyawan. Ke dua terdapat pengaruh antara budaya organisasi terhadap turnover intention karyawan. Ke tiga terdapat pengaruh antara motivasi terhadap turnover intention karyawan. Selanjutnya, kesimpulan empat yaitu motivasi memediasi antara budaya organisasi terhadap turnover intention karyawan di Jabodetabek.

Kata Kunci: Budaya Organisasi, Motivasi, Turnover Intention, Generasi Milenial

How to Cite: Sukmasari, A. (2020). Factors That Affect Turnover Intention in Millennial Employees. IndoFintech Intellectuals: Journal of Economics and Business, 1(1), 01-10. http://doi.org/10.54373/ifijeb.v1i1.8 


\section{INTRODUCTION}

Human resources are said by Dessler (2015) as an important asset for the company, because human beings are the resources that companies always need. Increasing competition for human resources as employees requires a strategic approach by managers and company leaders in order to meet employee satisfaction, motivation and increase commitment (Sada, Esmael dan Faisal, 2017), which if the needs of employees are not met properly, it can decrease work motivation so that there will be turnover intention. This is supported by the results of Imran research (2017); Shareef dan Atan (2018) that work motivation affects turnover intention. An employee who commits turnover intention, it will bring losses to the company.

Turnover intention is a situation where employees have the intention to find other jobs as an alternative to different companies (Abdullah dan Musa, 2011). Seeing that, the company needs to build an organizational culture that can motivate its employees and can keep employees motivated in their work so as to decrease the intention to switch jobs. Seperti Ciuhan dan Alexandru (2014); Matko dan Takacs (2017); Sada et al. (2017) who said the culture of the organization has an influence on the work motivation of employees. So it can be said that the better the organizational culture, the higher the level of motivation of employees. Therefore, managers need to understand what and how to motivate employees, as it is the most complex task (Matko dan Takacs, 2017).

In addition to employee motivation, the culture of organsiasi is expected to be well received by employees so as to minimize turnover intention. Where Robbins (2015) says the organization's strong culture leads to behavior, commitment, compactness, and a reduction in intention to move. Thus, organizational culture has an influence on turnover intentions (However, this is different from the results of Noerchoidah research (2020) on hotel employees in Surabaya that the culture has no effect on turnover intention, where most employees still have a period of work that is not too long so it has not really been able to adjust to the culture within the company.

Bosomtwe dan Obeng (2018) employees will voluntarily switch workplaces if they feel there are other better opportunities than their current position (more recognition, higher salaries and more convenient locations). While in Masfufah (2016) found results that employee work motivation has no effect on turnover intention, which in the research Putrianti, Hamid dan Mukzam (2014); Imran (2017); Shareef dan Atan (2018) say motivation has an influence on turnover intentions. Therefore, human resource management policy, 
especially in efforts to minimize turnover intention level must focus on understanding related factors that affect it (Putrianti et al, 2014).

This research will focus on millennial employees judging by organizational culture factors and motivation to suppress turnover intention rates. Therefore, the challenges of today's companies revealed by Dyastuti dan Sarsosno (2020) are how the company maintains, maintains and minimizes turnover intentions in millennial employees. Sheahan (2008) said millennial employees tend to have higher turnover rates when compared to previous generations. This is reinforced by Ivanovic dan Ivancevic (2019) that millennial employees were found to have a higher level of intention to move than in previous generations. Similarly, the research of Dyastuti dan Sarsono (2020) concluded that millennials will easily leave their current job if their career goals are not achieved in the company where they work. Generational differences will certainly have different characters and mindsets, so they will form their own personalities (Kampf, Lorincova, Hitka dan Stopka, 2017).

Robbins (2015) said the parties that can win the competition are those who have a strong culture of organiation, namely those who have an understanding of the core values that the organization has. It is hoped that the creation of a strong culture will increase employee motivation (Kim, 2017; Bosomtwe dan Obeng, 2018; Kwakye, 2018) so that it will decrease the interest of employees to switch workplaces and employees will work optimally. If there are obstacles in working, employees will try hard to solve it and not easily despair. Therefore, the purpose of this study is to find out the influence of organizational culture on turnover intention and work motivation on turnover intention in millennial employees in Jabodetabek area.

\section{METHOD}

This research is deductive, with exogen variables (organizational culture) and endogenous variables (motivation and turnover intention). The population in this study employees of millennials with purposive sampling method criteria are millennial employees in the Jakarta area who work in private companies with a range of 20 years - 38 years of age that is in accordance with the provisions of Howe dan Strauss (2000) where the birth of millennials ranged from 1982 to 2000 and has worked in private companies for at least one year. Analysis tools used Structural Equation Model (SEM) Lisrel software then the number of samples in sem provisions, at least 5-10 times the number of questionnaires (Hair, Anderson, 
Tatham dan Black, 2014), so that the number of samples obtained as many as 145 respondents (29x5) because there are known 29 statements in this study.

While the measurement of organizational cultural variables adopted from Denison (1990) in Magsi et al. (2018), on the measurement of motivational variables adopted from McClelland (1987) in Sukmasari (2016) and for the measurement of turnover intention variables adopted from Mobley et al. (1978) in Foon, Leong dan Osman (2010). While the data were obtained by disseminating questionnaires using alternative likert-scale method answers which included a score of five strongly agreed assessments (SS), a score of four agreed assessments $(\mathrm{S})$, a score of three neutral assessments $(\mathrm{N})$, a score of two disagreeing assessments (TS) and a score of one strongly disagreed assessment (STS) (Azwar, 2016). Furthermore, validity test of 30 respondents using confirmatory factor analysis results showed all kesioner statements on organizational cultural variables, motivation and turnover intention has been declared valid, provided that kmo value and MSA anti image correlation > 0,500 with 1 component matrix. In the reliability test alpha cronbach $>0.6$ showed good reliability (Sekaran dan Bougie, 2017). The results in this study were all variables expressed reliabel with alpha cronbach > 0,6 .

\section{Hypothesis Development}

\section{The Organization's Cultural Relationship to Motivation}

Human resources in work must have motivation and passion (Robbins, 2015). To foster the motivation of employees, of course, the company must have a strong organizational culture so that it is expected to produce the best performance. Good performance is said as important for the success of the company. It is according to Sada et al. (2017) that organizational culture affects employee work motivation. Matko dan Takacs (2017) explained that if the company creates a strong organizational culture, it will create motivation so that the work will increase. Some of the results of previous research conducted by Ciuhan dan Alexandru (2014); Matko dan Takacs (2017); Sada et al. (2017) has stated that there is an influence between organizational cultures on employee motivation. Based on the literature above, the hypotheses that can be proposed:

$\mathrm{H}_{1}$ : Strong organizational culture will increase motivation in employees

\section{The Organization's Cultural Relationship to Turnover Intention}

Organizational culture is one of the important factors for determining the suitability between employees and companies, where employees who match the organizational culture 
will have a smaller turnover intention towards other companies (Noerchoidah, 2020). Saputra (2017) said that organizational culture is not just a regulation that must be lived but the awareness of each member of the company to realize what must be done to achieve the company's goals, so as to reduce the intention to move. This is supported by Kim (2017); Bosomtwe dan Obeng (2018); Kwakye (2018) that organizational culture has an influence on turnover intentions. Based on the literature above, the hypotheses that can be proposed:

$\mathrm{H}_{2}$ : Strong organizational culture will reduce employee turnover intentions

\section{Motivational Relationship to Turnover Intention}

Providing the right employee work motivation will certainly improve employee performance so that the company's goals will be achieved (Putrianti et al, 2014). Robbins (2015) suggests achieving corporate goals, motivation as behaviors that explain the direction, intensity and perseverance of an individual. The onset of motivation can reduce problems such as one's transfer intentions, indiscipline, complaints and so on (Matko dan Takacs, 2017). It can be said that the desire of employees to come out is an indicator of the extent to which employee motivation can keep employees motivated to work so that employee performance is improved. With the motivation to create a sense of kinship so that the company considers very important, this can minimize employee turnover intention. Some research results such as Putrianti et al. (2014); Imran (2017); Shareef dan Atan (2018) stated that there is an influence between motivation on employee turnover intention. Based on the literature above, the hypotheses that can be proposed:

$\mathrm{H}_{3}$ : High motivation will decrease employee turnover intention

The description above, the research model can be described as follows:

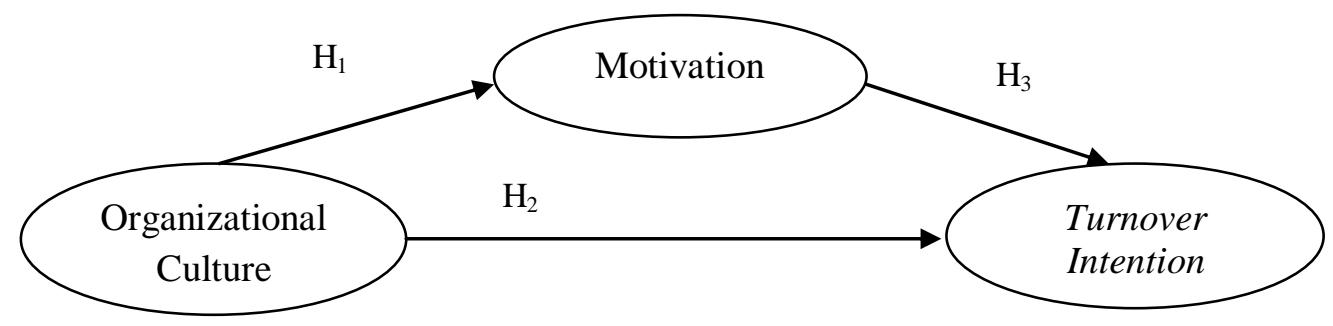

Figure 1. Research Model Diagram

\section{RESULTS}

This research analysis method SEM with Lisrel software, research focus on millennial employees in the Jakarta area and has worked in private companies for at least one year with as many as 145 samples as respondents. It can be said that the number of respondents already 
represented to conduct the research, which is the appropriate sample size with Hair et al. (2014) the number of samples should be greater than 100 respondents. Furthermore, the results of analysis with SEM showed, firstly, the measurement of construction validity test in this study results showed all acceptable, where all indicators on organizational cultural variables, motivation and turnover intention have a valid loading factor value $(>0,50)$, and a valid t-value $>1,96$ at a significance level of $5 \%$. The construction reliability test results meet the reliable requirements if the CR (Construct Reliability) value is above 0,60 and the VE (Variance Extracted) value is above 0,50 (Hair et al. 2014). CR values in all variables meet the reliabel requirement of organizational culture $(0,85)$, motivation $(0,89)$, and turnover inetntion $(0,96)$. Ve values all qualify reliabel i.e. on organizational culture $(0,60)$, motivation $(0,73)$, and turnover inetntion $(0,84)$.

The second analysis in sem structural test results is by looking at the $\mathrm{R}^{2}$ value for each equation serves to show how far independent variables are able to explain dependent variables. The first analysis of motivation (M) was influenced by organizational culture (BO) with $\mathrm{R}^{2}$ of 0,65 . This means that $65 \%$ of the motivation can be explained by organizational culture, while the remaining $35 \%$ can be explained by other variables not in this study. The analysis of both turnover intention (IT) was influenced jointly by organizational culture (BO) and motivation $(\mathrm{M})$ with $\mathrm{R}^{2}$ of 0,72 . This means that $72 \%$ of turnover intentions can be explained by organizational culture and motivation, while the remaining $28 \%$ can be explained by other variables not found in this study.

Further than the third analysis, the model conformity test almost all tests showed a good match including Chisquare, RMSEA, ECVI, Fit Index, AIC and CAIC. While in Critical N and and Goodness of Fit shows marginal fit. So it can be concluded that the suitability test of all models meets the requirements of good fit because 5 tests still show a good fit. Furthermore, the following can be seen the path of the T-Value diagram of the results

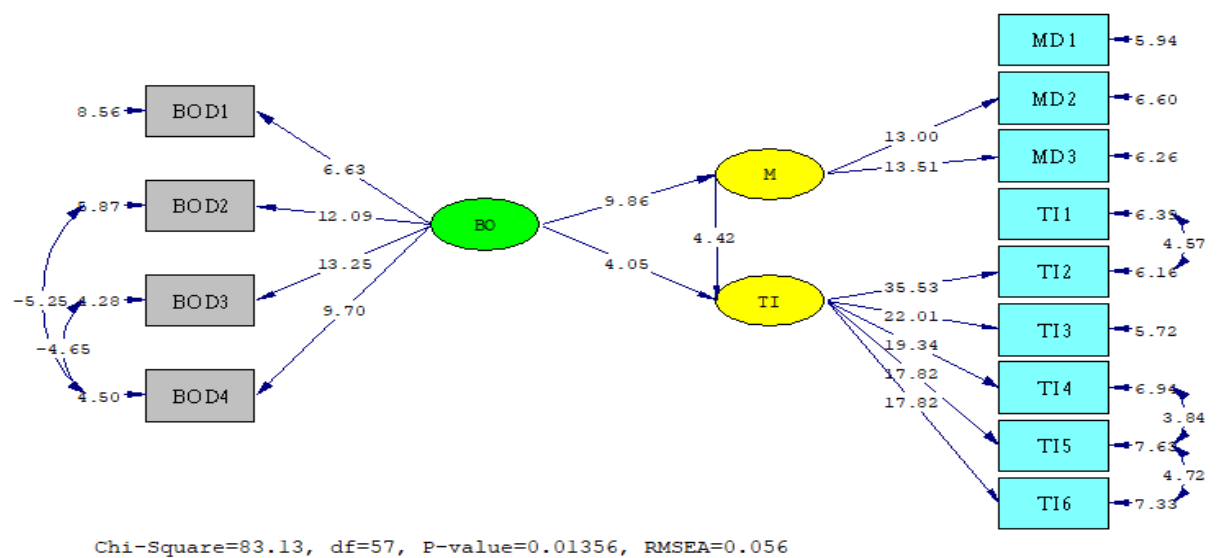

Figure 2. Path diagram t-value 
Based on the path of t-value diagram (Figure 2), it can be concluded that the research model hypothesis test in Table 1 is below:

Table 1. Hypothesis testing of research models

\begin{tabular}{lcc}
\hline \multicolumn{1}{c}{ Hypothetical statement } & T-Value & Decision \\
\hline $\begin{array}{l}\text { A strong organizational culture will increase motivation } \\
\text { in millennial employees }\left(\mathrm{H}_{1}\right) \text {. }\end{array}$ & 9,86 & $\begin{array}{c}\text { Hypothesis } \\
\text { accepted }\end{array}$ \\
$\begin{array}{l}\text { A strong organizational culture will reduce turnover } \\
\text { intentions in millennial employees }\left(\mathrm{H}_{2}\right) \text {. }\end{array}$ & 4,05 & $\begin{array}{c}\text { Hypothesis } \\
\text { accepted }\end{array}$ \\
$\begin{array}{l}\text { High motivation will reduce turnover intention in } \\
\text { millennial employees }\left(\mathrm{H}_{3}\right) \text {. }\end{array}$ & 4,42 & $\begin{array}{c}\text { Hypothesis } \\
\text { accepted }\end{array}$ \\
\hline
\end{tabular}

Source: SEM data processing software Lisrel

\section{DISCUSSION}

The results of the first hypothesis (H1) test showed that organizational culture has an influence on the motivation of millennial employees in the Greater Jakarta area. This means that the stronger the strong organizational culture, the more motivated employees will be. This is supported by the research results of Ciuhan dan Alexandru (2014); Matko dan Takacs (2017); Sada et al. (2017) that organizational culture has an influence on employee work motivation. The result of dimensional research that most supports motivation is the adaptability dimension where the organization holds norms and beliefs that support the company's capacity to accept, interpret and be sensitive to signs of the environment into changes in internal behavior. It can be said that millennial employees are able to adapt to the culture created, on the contrary from the company can understand the entry of millennials as new generation workers. Meier, Austin dan Crocker (2010) said it's important for companies to understand new employees in millennials in order to achieve the company's future progress.

The results of hypothesis two $(\mathrm{H} 2)$ test showed that organizational culture affects the turnover intention of millennial employees in Jabodetabek area. This means that the stronger the organizational culture, the lower the intention of employees to move in search of a new company. This is supported by Kim (2017); Bosomtwe dan Obeng (2018); Kwakye (2018) that organizational culture has an influence on turnover intentions. As the first hypothesis discusses, when viewed in terms of dimensions, that the dimension of organizational culture adaptation is what plays an important role in reducing the intention to move millennial employees. The culture of the organization created (acceptable regulations, comfortable environment, capable facilities, etc.) is able to make them easily adapt, so it will make them think again if they leave the company today, it will be a lot of losses experienced. 
The results of hypothesis three (H3) test showed motivation to influence the turnover intention of millennial employees in Jabodetabek area. It can be said that high motivation can decrease the turnover intention of millennial employees. The high motivation of employees does not escape the role of the organization how to treat its employees. The opportunity to get career development, promotion of positions can make millennial employees feel safe about their career path in the organization. Not only that, millennial employees are satisfied and happy, if their work can be recognized and appreciated well by superiors. The many benefits that employees receive both monetary and non-monetary motivate them to work better and minimize turnover intentions. Millennial employees can rethink if they want to leave the organization, because they don't necessarily benefit the same or more from their current organization. Some of the results of previous research conducted by Putrianti et al. (2014); Matko dan Takacs, 2017; Imran (2017); Shareef dan Atan (2018) have stated that there is a motivational influence on employee turnover intention

\section{CONCLUSION}

Based on the results of this research, it can be concluded that all hypotheses support previous research: (1) There is an influence of organizational culture on the motivation of millennial employees; (2) There is an influence of organizational culture on turnover intentions on millennial employees; (3) There is an influence between motivation and turnover intention in millennial employees; (4) It is found that motivation is able to mediate between organizational culture towards turnover intention in millennial employees in Jabodetabek area.

\section{RECOMMENDATIONS}

Referring to the weaknesses of this research, there are several limitations of research, namely (1) variables used as a benchmark for turnover intention only organizational culture and motivation; (2) It is likely that the respondents did not fill out a questionnaire based on the current condition. Among the suggestions for research development is to add other variables that can reduce the turnover intention of millennial employees such as variable perception of organizational support, compensation and so on so as to improve employee performance. 


\section{REFERENCES}

Abdullah, R., and Musa, M. 2011. The Study of Employee Satisfaction and Its effects towards Loyalty in Hotel Industry in Klang Valley, Malaysia. IInternational Journal of Business and Social Science. 2(3), 147-155.

Al-Sada, M., Esmael, B., and Faisal, M. N. 2017. Influence of Organizational Culture and Leadership Style on Employee Satisfaction, Commitment and Motivation in The Educational Sector in Qatar. EuroMed Journal of Business. 12(2), 163-188.

Azwar, S. 2016. Metode Penelitian. Yogyakarta: Pustaka Pelajar.

Bosomtwe, T.E., and Obeng, B. 2018. The Link between Organizational Culture and Turnover Intention among Employees in Ghana. International Journal of Contemporary Research and Review. Vol 9. Issue 08.

Ciuhan, G., and Alexandru, I. 2014. Organizational Culture Versus Work Motivation for The Academic Staff in a Public University. Procedia - Social and Behavioral Sciences. 127, 448-03.

Dessler, G. 2015. Manajemen Sumber Daya Manusia. Jakarta: Salemba.

Denison, D.R. 1990. Corporate Culture and Organizational Effectiveness. New York: John Willey \& Son.

Dyastuti, I.S., dan Sarsono. 2020. Pengembangan Karir terhadap Intensi Turnover pada Karyawan Generasi Milenial. Jurnal Psikologi Talenta. Vol 5. No 2.

Ertas, N. 2015. Turnover Intentions and Work Motivations of Millennial Employees in Federal Service. Public Personnel Management. Vol 44(3), 401-423.

Foon, F.C.B., Leong, L.C., and Osman, S. 2010. An Exploratory Study on Turnover Intention among Private Sector Employees. International Journal of Business and Management. Vol 5(8), 57-64.

Hair, J.F, Black, W.C. Babin, B. J. Anderson, R. E. 2014. Multivariate Data Analysis. In Exploratory Data Analysis in Business and Economics. Seventh Edition. USA: Prentice Hall International.

Hasibuan, M.S.P. 2017. Manajemen Sumber Daya Manusia. Edisi Revisi. Jakarta: Bumi Aksara.

Howe and Strauss. 2000. Millenials Rising. The Next Great Generation. New York. Vintage Books

Imran, M. 2017. Impact of Intrinsic Factors of Motivation on Employee's Intention to Leave: A Case Study of Health Department District Okara Punjab, Pakistan. Arabian Journal of Business and Management Review. Vol 7. 3.

Issa, D.A.R.M., Ahmad, F., Gelaidan, H.M. 2013. Job Satisfaction and Turnover Intention Based on Sales Person Standpoint. Middle East Journal of Scientific Research. 14 (4). 525-531.

Ivanovic, T., and Ivancevic, S. 2019. Turnover Intentions and Job Hopping among Millennials in Serbia. Management: Journal of Sustainable Business and Management Solutions in Emerging Economies. Vol 24(1), 53.

Kampf, R., Lorincova, S., Hitka, M., and Stopka, O. 2017. Generational Differences in the Perception of Corporate Culture in European Transport Enterprises. Sustainability. Vol. 9.

Kim, C.C. 2017. Intentions to Turnover: testing the moderated effects of organizational culture, as mediated by job satisfaction, within the Salvation Army. Leadership \& Organization Development Journal. Vol 38. Iss 2.

Kim, J. 2017. The Contrary Effects of Intrinsic and Extrinsic Motivations on Burnout and Turnover Intention in The Public Sector. International Journal of Manpower. Vol 39(3), 486-500. 
Kwakye, E. O. 2018. Organisational Culture and Employee Turnover: Evidence from Ghana. Journal of Economics, Management and Trade. 21(2): 1-11.

Kusdi. 2011. Budaya Organisasi. Jakarta. Salemba Empat.

Magsi, H.B., Ong, T.S., Ho,J. A., and Hassan, A.F. S. 2018. Organizational Culture and Environmental Performance. Sustainability (Switzerland), 10(8), 1-17.

Masfufah, E. 2016. Pengaruh Motivasi Kerja dan Kepuasan Kerja terhadap Turnover Intention (Studi pada PT Citra Perdana Kendedes Malang. Jurnal Ilmiah Mahasiswa FEB. Vol 5. No 2.

Matko., and Takacs. 2017. Examination of The Relationship between Organizational Culture and Performance. Int. Rev. Appl. Sci. Eng. 8. 99-105.

McClelland. D. 1987. Human Motivation. New York: Cambridge University Press.

McClelland, D. 2012. Teori Motivasi. Jakarta: PT. Bumi Aksara.

Meier, J., Austin, S.F., and Crocker, M. 2010. Generation Y in the Workforce: Managerial Challenge. The Journal of Human Resource and Adult Learning. 6. 68-79.

Mobley, W.H., Horner, S.O., \& Hollingsworth, A.T. 1978. An Evaluation of Precursors of Hospital Employee Turnover. Journal of Applied Psychology. 63(4), 408-414.

Noerchoidah. 2020. Turnover Intention Karyawan: Pengaruh Budaya Organisasi, Organizational Justice dan Kepuasan Kerja. Jurnal Manajemen, Strategi Bisnis dan Kewirausahaan. Vol. 14, No. 2.

Putrianti, A.D., Hamid, D., dan Mukzam, M.D. Pengaruh Kompensasi dan Motivasi Kerja terhadap Turnover Intention (Studi Pada Karyawan PT. TIKI Jalur Nugraha Ekakurir Pusat Malang). Jurnal Administrasi Bisnis. Vol. 12 No. 2.

Robbins, S. 2015. Perilaku Organisasi. Jakarta: Salemba Empat.

Sabir, M.S., Jam, J.I., Kasif, R., Kamran, A.S, and Yameen, M. 2012. Impact of Corporate Ethical Vaulues on Ethical Leadership and Employee Performance. Journal of Business and Social Science. 3 (2). 163-171.

Sekaran, U., and Bougie, R. (2017). Metode Penelitian untuk Bisnis Pendekatan Pengembangan-Keahlian. Jakarta: Salemba Empat.

Shareef, R.A., and Atan, T. 2018. The Influence of Ethical Leadership on Academic Employees' Organizational Citizenship Behavior and Turnover Intention Mediating Role of Intrinsic Motivation. Management Decision. Vol. 57.

Sukmasari, A. 2016. Analisa Motivasi Kerja dan Komitmen Organisasional sebagai Konsekuensi dari Keterlibatan Kerja (Studi pada Pegawai Non Dosen Universitas Esa Unggul). Tesis. Jakarta: Universitas Esa Unggul. 